\title{
Emotional Support - Methodological Aspects of Measuring the Quality of Comfort-intended Communication
}

\begin{abstract}
The aim of this article is to present methodological aspects of research on comforting language skills, evaluating the quality and sophistication of supportintended messages, and explaining key factors underlying the potential effectiveness of emotional support in case of "emotional conflicts". Research proves that the core of support-intended message is "person centeredness", defined as the ability to explicitly acknowledge and elaborate, legitimize the subjective perspective of a distressed partner [Burleson 2010]. Empirical operationalization of this concept underlies the development of hierarchical coding system for sensitivity of comforting strategies, which nowadays is one of the most popular tools to evaluate the quality of supporting communication. The main assumptions of this coding system have been presented, together with its structure and criteria of analyzing the potential comforting effectiveness. At the end, cultural stereotypes and misconceptions descending the quality of support-intended behaviours were addressed.
\end{abstract}

Key words: emotional support, comforting message, hierarchical system for evaluating comforting messages' sensitivity.

\section{Introduction}

Providing effective emotional support is widely recognized in psychology as one of the most difficult interpersonal situations. Many researchers claim it to be a core aspect of communicative competence of any human being: the ability responsible for building close interpersonal relationships, crucial factor in interaction management, the essential skill for many professions based on social contacts. Although a concept of emotional support is often used in pedagogical 
and psychological literature, there is comparatively little scientific research concerning that problem. The available literature usually focuses on a narrow or instrumental view of the issue, and considers emotional support a specific skill which emerges in a specific context, in relation to particular needs or people. Know-how literature, which can easily be found, presents advices for:

- nurses and caregivers of people suffering from chronic or terminal illnesses in hospitals, clinics or rehabilitation units,

- career counselors and coaches working with unemployed people,

- social workers providing job seeking assistance and welfare to people in difficult life situations, recovering from addictions, or suffering from learned helplessness.

Each of the aforementioned groups requires a different attitude as well as different methods and solutions; however, the above approach overlooks the wider perspective in which the ability to emotionally support their partner is part of people's everyday life. Such support might be needed by a child who failed a test at school; a spouse fearful of speaking in public; a friend worried that his girlfriend is cheating on him; a young mother on the brink of postpartum depression, etc. These situations usually put people in an awkward position, as difficult, delicate, deeply personal and often painful or sensitive matters are introduced into conversations. We seldom know how to support someone who is dealing with a problem and hardly ever know how to talk about it. In most of the cases we do not know what to say or we make inappropriate statements, for instance: "I wish I had your problems!" or "Really, in Ethiopia children are starving - these are real problems". Such statements will not make trouble disappear, but they can stop the other person from talking about it, and be strong grounds for feeling neglected, rejected and insignificant [Salmon 2002; Winch 2013].

Therefore, emotional support is a form of social behavior, a linguistic ability to react to situations which are difficult (objectively or subjectively) for our interlocutor to deal with. Language plays a special role in this process, as it is the most powerful and precise instrument affecting inner states and attitudes of others. Not only does it provide resources and strategies for persuasion but, according to Sapir and Whorf [Nęcki 1996], it also constitutes a cognitive filter in our perception; it influences reality by shaping its representation in people's minds. This paper aims to present such a broad, linguistic perspective on emotional support. The aim is to present methodological aspects of measuring comforting language skills, evaluating the quality/ sophistication of support-intended messages, and explaining key factors underlying the potential effectiveness of emotional support. 


\section{Defining support-intended behavior - socio-linguistic aspects}

The term "emotional support" is most frequently used in social psychology to refer to a particular type of social interaction, which is undertaken in a difficult situation - problematic or stressful for one of the partners [Salmon 2002, pp. 43-44]. Two distinctive factors seem to be essential in describing "supportive" interaction:

- such communicative exchange aims to help the distressed person to understand, elaborate and cope with his/ her own negative feelings;

- complex dynamics of the interaction is governed by deep, emotional interplay between partners. The effectiveness of such exchange is highly subjective, however. Although the physical presence of others, face-to-face contact and non-verbal behaviors might be very helpful, they are not automatically perceived as a form of efficient support. The supportive impact of the situation is often described in terms of "concern" and "respect" - in other words, a distressed partner is most likely to assess the interaction as emotionally supportive when he is aware of somebody's understanding and respect for his own fears, anxiety or sadness, when he gets the possibility to open up.

This subjectivity of perception should be seen as a main obstacle in conducting scientific research on emotional support - emotional aspects of human interactions are relatively difficult to operationalize and assess. Many researchers claim that, although global concepts such as "perceived concern", "sensitive listening" or "helpful verbalization" are useful for certain purposes, they do comparatively little to aid scientific understanding of the precise constituents of "emotionally helpful communicative strategy" [Burleson 1982, p. 1578]. Such constituents should be defined in terms of the impact on a distressed partner's feelings - support-intended behavior will be effective as long as: $1 /$ it enables the interlocutor to express openly his/her negative feelings; $2 /$ it helps to cope with the stress and keep it below the critical level; 3 / it facilitates searching for a constructive solution of a problem or difficulty which became a source of a distress. The essence of emotional support is not just expressing general concern or understanding for a partner, but rather strengthening the level of his self-esteem. Helping the partner to build a positive sense of self will bring positive results on two levels: intrapersonal, by increasing partner's innate powers necessary to fight against the problem, and interpersonal, by transforming the relation and bringing it into a deeper, more intimate level (fig. 1). Emotional support should therefore be considered as a complex, multifaceted phenomenon, and a product of cognitive, social and language development. 
Figure 1. Emotional support as a multifaceted phenomenon
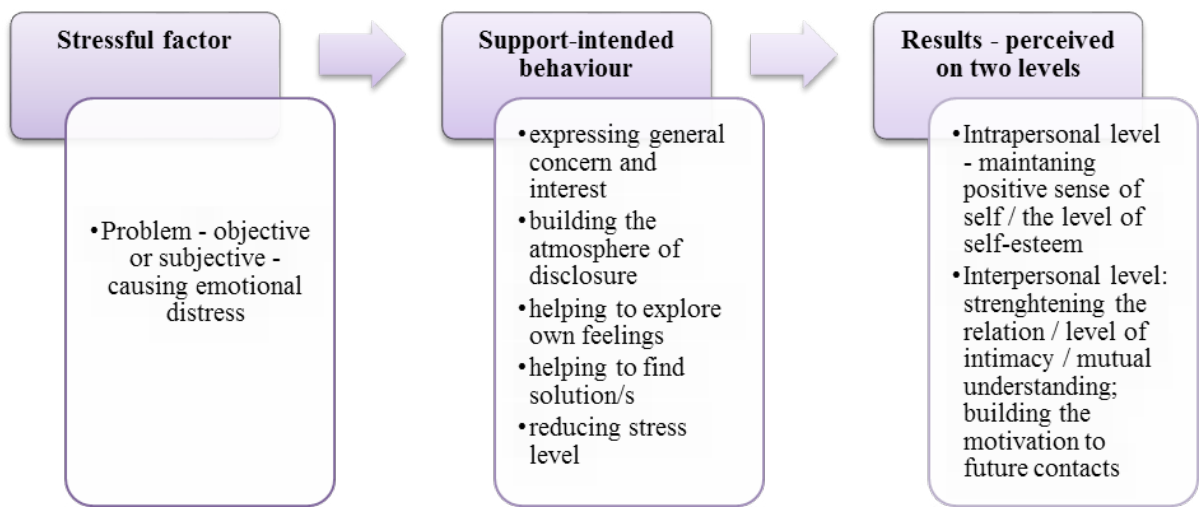

Source: own work.

The term "emotional support", in pedagogical literature as well as in colloquial use, is often erroneously associated with concepts of empathy and sympathy. However, these concepts hold different meanings. At the core of empathy lies consideration, the ability to observe, understand and share the emotional states of another person [Kielar-Turska 2002; Barnett 1984]. Sympathy relates to a narrower range of phenomena and is born out of appreciation for life's difficulties, distress, or bewilderment experienced by another person. Therefore, our sympathy is aroused under conditions of upset, stress and negative experiences, whereas empathy is associated also with positive feelings such as joy, hope, pride. Sympathy is semantically not equivalent to emotional support - we can sympathize deeply with someone and still do nothing to help them. The essence of support is providing emotional assistance, moving beyond the sphere of sentiment and proceeding into action. This requires not only the ability to understand other people's state of mind, attitudes and emotions but also the motivation to engage in support-intended behavior, and competence to conduct it effectively.

The concept closely connected with emotional support, frequently used as semantically equivalent, is comforting. According to Longman Dictionary of Contemporary English "if someone or something gives you emotional comfort, they make you feel calmer, happier or more hopeful after you have been worried or unhappy" [2003, p. 302]. Communication Encyclopedia defines comforting as a form of prosocial behavior, behavioral empathy or social support used in interpersonal communication to assist the other's problem-solving in a troublesome situation - "comforting communication encompasses the verbal and nonverbal messages that people use when trying to reduce others' emotional 
anguish" [2015]. Thus, both terms, comforting and emotional support represent the same type of strategic communication activity.

From linguistic point of view the core of support-intended behavior is the ability to construct a particular type of expressions - "messages having a goal of alleviating or lessening the emotional distress experienced by others" [Burleson 2010, s. 179].

Empirical research on emotional support includes mainly two lines of considerations. Speech act theory considers support-intended verbalization as an important dimension of language pragmatics. As J. Austin [Nęcki 1996] argues, every use of language has inevitably pragmatic character - there is a particular intention underlying every language behavior, the purpose which determines the choice of words we use, syntactic structures shaping a sentence, ways of expressing the intended meaning. On the other hand, every language behavior causes particular results in environment, implies some consequences, e.g. makes an impact on partner's feelings and behaviors, defines or modifies their mutual relations, changes the context of communication in a particular way (intended and desired or, on the contrary, unexpected and unwelcomed). Pragmatic aspect of communicative competence involves the knowledge of cultural rules of language use in a particular social context, rules of "cultural appropriateness". Following these rules enables the person to achieve important interactional aims in a way which is both effective and culturally correct (accepted), suitable to the social context of speaking: place, time, topic of conversation, interlocutor's needs, etc.

In the area of interpersonal communication emotional support is considered as one of the most important provisions of human social relationships - psychological procedure of building proximity, intimacy, and mutual understanding. Supportive involvement in conversation, providing sensitive psychological comfort and understanding to the partner's feelings constitute an important determinant of communicative effectiveness and stability, emotional strength of relationship bonds. Emotional support seems to be especially important in romantic relationships - serving as an equity mechanism to balance the fragile receipt of mutual rewards and costs. In other words, comforting is used as a method to maintain an equitable relation or as a tool to restore equity to an unbalanced relationship [Henningsen, Serewicz, Carpenter 2009]. The research proves that individuals more or less consciously regulate the extend and quality of comfort provided to the partner, according to how they perceive their own situation in a relation: ,when individuals gauge supportiveness in their relationships, they use comforting as a balancing mechanism, improving the sophistication of comforting when they are over-benefited and reducing it when they are underbenefited" [Henningsen, Serewicz, Carpenter 2009, s. 362]. As a result, enacting high-quality comforting behavior influences directly the overall perception of 


\section{Dorota Zdybel}

supportiveness within the relationship - sophisticated comforting techniques, demanding a high level of psychological and intellectual efforts are perceived as a partner's particular concern for carving out the quality of relational bonds, a sort of yardstick of his/ her involvement, and one of the key predictors of relational satisfaction/ dissatisfaction.

B.R. Burleson stresses one more, rarely explored aspect of emotional support, bridging the interests of psychology and medicine - „Less obviously, the comfort that we receive from others can protect our health and may even help us live longer. A growing body of research indicates that the stress that accompanies emotional upset can be harmful to our health, particularly if that emotional stress is frequent and/or enduring. By reducing emotional upset, effective comforting can diminish the health-harming effects of stress on the cardiovascular system, the neuroendocrine system, and the immune system" [Burleson 2010, p. 180]. Therefore, supportive social network should be seen as an important condition of both, physical health and psychological well-being - numerous research indicates that ,the recipients of sensitive emotional support can recover more quickly from various illnesses and injuries and may even live longer when battling afflictions such as heart disease or breast cancer. In sum, the receipt of sensitive emotional support contributes substantially to multiple indices of personal and relational well-being" [Burleson 2003, p. 2].

In such context it is worth asking the question: how people evaluate the level of quality and sensitivity of emotional support? What properties and characteristics determinate perceiving a particular behavior as more/ less helpful? What should characterize a high-quality, sophisticated supporting message?

\section{Measuring support-intended behavior - methodological aspects}

Psychological research has identified several aspects of support-intended communication strategies which are perceived as sophisticated, sensitive and helpful [Henningsen, Serewicz, Carpenter 2009, p. 355]:

- supportive communication is "listener centered" - it attempts to discover the other person's perspective, the unique, subjective way of perceiving and experiencing the particular situation;

- supportive message tends to focus on a proximate rather than the distal causes of a distress - on partner's psychological reactions to the event rather than on the event itself. Searching for rational causes in the area of emotional states is not a very constructive strategy. After all, the same external event might be the source of positive or negative emotions for different people, and the very process of seeking for objectivity or rationality in their internal, subjective experiences resembles rather scratching the psychological wounds than easing the pain and suffering; 
- support-intended message is therefore non-evaluative, accepting to the distressed other, seeking an explanation and understanding of the partner's feelings, and offering the help to better insight into their nature and consequences. Guy Winch [2013] identifies that process as „psychological validation” or "legitimization of feelings” - accepting the partner's right to negative feelings, allowing him to live through whatever he experiences without criticizing, questioning, denying or telling him "to hold on". After all, "emotions are real, we cannot deny that someone feels something - even if the thoughts underlying his emotional states are based on incorrect or misguided process of reasoning. It is impossible to diagnose it is not truth that you feel what you feel" [Skorupa 2014, p.1]. On the other hand however, admitting the validity of someone's feelings itself, creating the space for expressing them, crying or shouting them out, might become a sort of catharsis, liberation, working as ,emotional first aid” for treating everyday psychological injuries [Winch 2013].

From methodological point of view, the essence of emotionally supportive communication can be best explained by the concept of "person centeredness" which "pertains to the extent to which messages explicitly acknowledge, elaborate, legitimize, and contextualize the feelings and perspective of a distressed other" [Burleson 2010, p. 181]. This concept has been used to construct hierarchical categorization of arguments employed to build comforting strategy - the coding system designed to evaluate the level of sensitivity of support intended message. The procedure was originally developed by J.L. Applegate, and then empirically verified and standardized by B.R. Burleson [1982; 1983]. Burleson suggests that three main types of emotional support strategies should be distinguished [2010, pp. 181-182]:

1. on the lowest level, support-intended message "denies the other's feelings and perspective by criticizing or challenging their legitimacy, or by telling the other how he or she should act and feel" - low person-centeredness;

2. on a slightly higher level, comforting message "affords an implicit recognition of the other's feelings by attempting to distract the other's attention from the troubling situation, offering expressions of sympathy and condolence, or presenting explanations of situation that are intended to reduce the other's distress" - moderate person-centeredness;

3. on a highest level, support-intended message explicitly recognizes and legitimizes the partner's feelings by helping him articulate and define them, elaborate the reasons why such feelings might be awakened, and explore how they fit in a broader context - high person-centeredness.

On each of the three levels Burleson recognized more detailed content categories of comforting argumentation with a clear emphasis on the fact that the 


\section{Dorota Zdybel}

whole coding system reflects the process of comforting skills development. The internal logic of this development is shaped by the interaction of two factors: a/ sensitivity to another person's perspective of experiencing the situation and b/ related ability to name and describe one's own and another person's feelings. The details of this evaluation procedure are presented in the table below.

B.R. Burleson has also designed a set of experimental tasks used to elicit comfort-intended messages in laboratory settings. These tasks were based on a description of a hypothetical social situation - an upsetting event initiated by emotional loss - the situation in which a distressed friend had to be comforted. The key to constructing such situation was a particular "conflict of emotional interests" between interactional partners, defined as a potential contradiction in feelings implied by the particular event, i.e. the same external circumstances would be a source of positive emotions for one participant (sender of the message), but for another participant (recipient of the message) would have a negative, strongly unpleasant and stressful character. Here is one example of such hypothetical situation - "Invitation to a birthday party" [Burleson 1984, p. 74]: „Suppose your best friend was not invited to a birthday party to another colleague of yours. You were invited, everybody else in your class were invited, but your best friend did not get the invitation. What would you say to make your friend feel better about not receiving the invitation? What else could you say?" The examples of answers provided were used in the table below to explain the sublevels of comforting message sensitivity.

Table 1. Hierarchical Coding System for Sensitivity of Comforting Strategies

\begin{tabular}{|l|l|}
\hline $\begin{array}{l}\text { Level of } \\
\text { sensitivity }\end{array}$ & Sublevels of Message Strategies \\
\hline $\begin{array}{l}\text { I. Denial of } \\
\text { individual } \\
\text { perspective }\end{array}$ & $\begin{array}{l}\text { The speaker condemns or ignores the specific feelings that exist In the } \\
\text { situation for the person addressed. This denial may be either explicit or implicit } \\
\text { Speaker condemns the feelings of the other („I would tell her she had no } \\
\text { reason to feel that way about not getting invited, and if she felt this way, she } \\
\text { was no friend of mine”). } \\
\text { Speaker challenges the legitimacy of the other's feelings (,There is nothing to } \\
\text { be upset about - it's just an old party”) } \\
\text { Speaker ignores the other's feelings („I would tell her there've been other } \\
\text { parties, and she should be happy about going to them”). }\end{array}$ \\
\hline
\end{tabular}




\begin{tabular}{|l|l|}
\hline $\begin{array}{l}\text { II. Implicit } \\
\text { recognition } \\
\text { of individual } \\
\text { perspective }\end{array}$ & $\begin{array}{l}\text { The speaker provides some implicit acceptance of and/or positive response } \\
\text { to the feelings of the others, but does not explicitly mention, elaborate, or } \\
\text { legitimize those feelings: } \\
\text { Speaker attempts to divert the other's attention from the distressful situation } \\
\text { and the feelings arising from that situation (“When it's my party, I will invite } \\
\text { you”). } \\
\text { Speaker acknowledges the other's feelings, but does not attempt to help the } \\
\text { other to understand why those feelings are being experienced or how to cope } \\
\text { with them („I am sorry you didn't get invited to the party. I am sorry you feel } \\
\text { bad”). } \\
\text { Speaker provides a non-feeling-centered explanation of the situation intended } \\
\text { to reduce the other's distressed emotional state (“Maybe your invitation to the } \\
\text { party got lost in the mail”). }\end{array}$ \\
\hline $\begin{array}{l}\text { III. Explicit } \\
\text { recognition } \\
\text { and } \\
\text { elaboration } \\
\text { of individual } \\
\text { perspective }\end{array}$ & $\begin{array}{l}\text { The speaker explicitly acknowledges, elaborates, and legitimizes the feelings } \\
\text { of the other. These strategies may include attempts to provide a general } \\
\text { understanding of the situation. Coping strategies may be suggested in } \\
\text { conjunction with an explication of the other's feelings: } \\
\text { Speaker explicitly recognizes and acknowledges the other's feelings, but does } \\
\text { not discuss the source of the feelings or the nature of the situation („I know } \\
\text { you feel bad about not going to the party, but you're my friend - lots of people } \\
\text { like you. When my party comes up, I will invite you”). } \\
\text { Speaker provides an elaborated acknowledgment and explanation of the other's } \\
\text { feelings (,I am really sorry about the party. I didn't mean to make you feel } \\
\text { bad by mentioning it, but I know I did. It's not fun being left out. Maybe it's a } \\
\text { mistake. I will talk to Sharon, ok?”) } \\
\text { Speaker helps the other to gain a perspective on his or her feelings and } \\
\text { attempts to help the other see these feelings in relation to a broader context } \\
\text { („I really understand how you feel, I haven't been invited to a special party } \\
\text { sometimes and I know it hurts - you can feel rejected. But maybe Jean really } \\
\text { wanted to have you, but her parents wouldn't let her invite everybody”). }\end{array}$ \\
\hline
\end{tabular}

Source: Burleson 1984, pp. 74-75.

It should be noted that the coding system presented above includes only verbal communication strategies. Non-verbal reaction techniques, offered in place of (or in line with) verbal communication, are not evaluated. Although it would be difficult to question the value of such behaviors in a specific communicative situation, their status appears unclear. Many researchers suggest that such behaviors serve to assist and supplement a verbal message; however they are not always socially desirable or acceptable [Angell 1998].

One of the most important assumptions of presented coding system is a hierarchical relationship between the described categories, which allows not only differentiating between message-strategies (derived from the presence or absence of specified features of the message), but also evaluating a particular strategy as 


\section{Dorota Zdybel}

"better" (i.e. more refined, sophisticated, subtle or sensitive, etc.), according to its place in the hierarchy. This, however, does not necessarily mean that strategies defined as "ones with a higher degree of sensitivity" in B.R. Burleson's coding system are in general more effective, successful or prosocial than the "less sensitive" ones. The actual effectiveness of a particular verbal behavior depends on a specific context, circumstances in which emotional tension appears, its cause, the recipient, etc. From communicative point of view, placing a particular strategy in a particular position in the hierarchy allows only to make assumptions about the range of reaction strategies or verbal patterns available to an individual - the use of a particular level of message strategy implies that the strategies from lower levels are already known to a subject, ready to be used when necessary. As B.R. Burleson states, "a child capable of using a high-level strategy explicitly elaborating and legitimizing the other's feelings (level 8) might employ a strategy diverting the other's attention from the distressful situation (level 4) if he thought the other's distressed state was relatively transient and that dwelling on that state would only exacerbate the situation" [1982, p. 1582]. On general the hierarchical order of message strategies proposed by Burleson is grounded in Bernstein's [1990] distinction between "restricted" and "elaborated" language codes and it presumes to reflect a developmental progression from position-oriented to person-oriented speech.

Therefore, while evaluating the potential efficiency of a particular comfortintended behavior or statement, it is important to consider not only the level of sensitivity to the partner's subjective viewpoint (affective decentration ability), but also the range and content variety of the employed line of reasoning. Variety of message strategies, defined as the number of qualitatively different levels of strategies used in responding to the situation has been widely recognized as a basic measure of communicative flexibility [Neccki 1996; Reardon 1987]. The richer and more substantial (i.e. the more internally diverse) is the repertoire of the individual's verbal behavior patterns, the more probable is that the individual will be more flexible and efficient in a particular situation requiring support than a person with a relatively narrow repertoire [Zdybel 2009].

On top of that, the newest research by Burleson and his colleagues [2010] proves that the efficiency of emotional support is not solely based on the level of quality or sophistication of comforting message itself. The outcomes of comforting communication, defined as an "affective change" in recipient's behavior (the size, depth, and character of such change), are the joint function of three crucial factors [Burleson 2010, p. 190]: a/ the content of supportive message (low person- centeredness versus high person- centeredness), b/ environmental cues in the situation which can trigger responses to the message, and $\mathrm{c} /$ the degree of scrutiny supportive messages receive from their addressee 
(i.e. attention, thought, elaboration, thoughtful versus superficial processing). "If supportive messages receive a high degree of scrutiny from recipients, then the outcomes of support situation will largely be influenced by aspects of message content (e.g. the sensitivity or person - centeredness of the supportive message). On the other hand, if supportive message receive little scrutiny, message content should have a smaller (and perhaps inconsequential) effect on outcomes; in such cases, other factors, including a variety of environmental cues (e.g., sex of the helper, attractiveness of the helper), may substantially influence outcomes of supportive encounter" [Burleson 2010, p. 190]. The above thesis, known as a "dual-process theory of comforting communication" is still in the process of empirical verification, revealing the actual complexity and depth of emotional support mechanisms. However, even on this stage it is clear that the comforting process is much more fragile and unpredictable than we could expect it.

\section{Avoiding cultural barriers and misconceptions - from technical aspects to the art of comforting}

Many researchers claim that most obstacles for emotional support in everyday life originate from socio-cultural misconceptions and/ or misconducts. There is a great discrepancy between psychological research results and common perception of what is a "helpful assistance" in distress, between what we tend to believe is helpful, and what really provides affective comfort. As V. Walker noticed, semantic root of the word "comfort" originates from Old French meaning ,to be strong with" rather than „being strong for somebody" - "being strong with someone means creating a sanctuary for someone in pain, a respite from the busy, indifferent world around us, just sitting down, listening, and allowing the person to acknowledge his or her pain" [Walker 2010, p. 8]. On the other hand, people grounded in western, "goal-oriented" and "solution-focused" culture expect the communication to be fast and efficient, providing quick and constructive help to the distressed other - "we like our efforts to work, to 'fix it' in a time-measured manner. We think that helping someone in pain means helping them 'get over' the problem" (...) But with comforting, communication can be slow, uneven, unpredictable, and confusing" [ibidem].

Several important differences between emotionally supportive communication and popular cultural perceptions of it can be distinguished [Walker 2010, pp. 9-11]: 
Table 2. Common misconceptions about effective support-intended behavior summary

\begin{tabular}{|c|c|}
\hline $\begin{array}{l}\text { Mainstream culture - } \\
\text { lay concepts, commonsense perception }\end{array}$ & $\begin{array}{l}\text { Comforting according to psychological } \\
\text { research }\end{array}$ \\
\hline $\begin{array}{l}\text { Finding solutions } \\
\text { We like to "fix it", get things working again. } \\
\text { We like to advise, to offer answers and } \\
\text { remedies. } \\
\text { We like to take problem-solving approach. }\end{array}$ & $\begin{array}{l}\text { We do offer our presence and thoughtfulness, } \\
\text { not solutions } \\
\text { We listen closely. } \\
\text { We wait, let the person find his own words. }\end{array}$ \\
\hline $\begin{array}{l}\text { Getting quick results } \\
\text { We like to be quick and efficient, always on } \\
\text { the go, on the clock. We like to release the } \\
\text { pain quickly. } \\
\text { We believe healing means to completely "get } \\
\text { over" our losses/ pains. }\end{array}$ & $\begin{array}{l}\text { We offer our time, don't rush, allow someone's } \\
\text { grief or trauma to take its own courses, have } \\
\text { its own pace. } \\
\text { Healing means learning to live with loss, } \\
\text { rather than getting over it completely. }\end{array}$ \\
\hline $\begin{array}{l}\text { Organizing } \\
\text { We like to know what will happen next. } \\
\text { We like to have instructions explicated. } \\
\text { We hate not knowing what to do/ say - we } \\
\text { avoid silence as awkward, embarrassing. }\end{array}$ & $\begin{array}{l}\text { We step into the present moment, let go of } \\
\text { expectations, accept that comforting can be } \\
\text { unpredictable, disorganized process. } \\
\text { We stay open, let the distressed person talk, } \\
\text { even if he/ she is upset. }\end{array}$ \\
\hline $\begin{array}{l}\text { Multitasking } \\
\text { We do as much as we can, working with } \\
\text { interruptions. We like to click phones, pagers, } \\
\text { IMs, iPods, faxes, have the TV on. }\end{array}$ & $\begin{array}{l}\text { We give our undivided attention, } \\
\text { communicate in a private, quiet, confident } \\
\text { setting, with no distractions in the room. }\end{array}$ \\
\hline $\begin{array}{l}\text { Avoiding negative emotions } \\
\text { We like to cheer people out when they are } \\
\text { down. We expect them to be strong, "hold on" } \\
\text { under pressure. } \\
\text { We like to use platitudes and teaching from } \\
\text { our favorite books, religions, mentors. We } \\
\text { offer popular sayings: "You'll be stronger for } \\
\text { this", "This too shall pass". }\end{array}$ & $\begin{array}{l}\text { We don't try to take their pain away, allow } \\
\text { them to feel what they feel. We respect a } \\
\text { person's right to be vulnerable, sensitive. } \\
\text { We offer to be a sanctuary, a safe person to be } \\
\text { with, when someone falls apart. } \\
\text { Platitudes feel impersonal and preachy. }\end{array}$ \\
\hline $\begin{array}{l}\text { Being product } \\
\text { We like to feel useful and helpful, to reassure } \\
\text { the distressed person that we understand } \\
\text { them. }\end{array}$ & $\begin{array}{l}\text { We accept we may never know if we helped } \\
\text { or how we helped. We admit we do not fully } \\
\text { understand their journey, but offer to learn } \\
\text { more about it together with them. }\end{array}$ \\
\hline
\end{tabular}

Source: own work. 
These two visions are so contradictory that learning the language of comforting has been compared by V. Walker to "learning the language of a whole different culture, of a foreign land where the customs differ significantly from what we have been socialized to do" [2010, p. 8]. However, becoming aware of these discrepancies is crucially important for professional and paraprofessionals, for whom support-intended communication as a part of their daily job: psychologists, therapists, teachers, social workers etc. Such awareness might be the first step from learning support-intended techniques to the art of comforting.

\section{Bibliography}

Angell L.R. (1998), Communication comforting strategies and social bereavement: verbal and nonverbal planning and appropriateness, "Journal of Personal \& Interpersonal Loss", Vol. 3, Issue 3, pp. 271-283.

Barnett M.A. (1984), Perspective taking and empathy in the child's prosocial behavior [in:] Sypher H.E., Applegate J.L. (eds.), Communication by Children and Adults. Social, Cognitive, and Strategic Processes, Sage Publications, Beverly Hills, London, New Delhi.

Bernstein B. (1990), The structuring of pedagogical discourse. Class, codes and control, Vol. 4, Routledge, London - New York.

Burleson B.R. (2010), Explaining recipient responses to supportive messages: Development and tests of a dual-process theory [in:] S.W. Smith, S.R. Wilson (eds.), New Directions in Interpersonal Communication Research, Sage Publications.

Burleson B.R. (2003), The experience and effects of emotional support: What the study of cultural and gender differences can tell us about relationships, emotions, and interpersonal communication, "Personal Relationships", Vol 10, pp. 1-23.

Burleson B.R. (1984), Comforting Communication [in:] H.E. Sypher, J.L. Applegate (eds.), Communication by Cbildren and Adults. Social, Cognitive, and Strategic Processes, Sage Publications, Beverly Hills, London, New Delhi.

Burleson B.R. (1982), The development of comforting communication skills in childhood and adolescence, "Child Development", No 53, pp. 1578-1588.

Communication Encyclopedia [on-line, 28.01.2015] http://www.communicationencyclopedia. com/public/tocnode?id=g9781405131995_yr2013_chunk_g97814051319958_,pp. 50-1.

Henningsen D.D., Serewicz M.C.M., Carpenter Ch. (2009), Predictors of Comforting Communication in Romantic Relationships, "International Journal of Communication", Vol. 3, pp. 351-368.

Kielar-Turska M. (2002), Średnie dziecinstwo. Wiek przedszkolny [in:] B. Harwas-Napierała, J. Trempała (red.), Psychologia rozwoju cz̧owieka, Tom 3, Roz̧wój funkciji psycbicznych, Wydawnictwo Naukowe PWN, Warszawa.

Longman Dictionary of Contemporary English (2003), Pearson Education Limited, Edinburgh UK.

Nęcki Z. (1996), Komunikacja miedzyludžka, Wydawnictwo Profesjonalnej Szkoły Biznesu, Kraków. 


\section{Dorota Zdybel}

Reardon K.K. (1997), Interpersonal communication: where minds meet, Wadsworth Publishing Company, Belmont, California.

Salmon P. (2002), Psychologia w medycynie: wspomaga współprace zpacjentem i proces leczenia, GWP, Gdańsk.

Skorupa M. (2014), 3 umiejętności, ketóre posiadly osoby w squęśsliwych qwiqzkach, „Gazeta Wyborcza" z dnia 29.04.2014 [on-line, 21.03.2015] http://zdrowie.gazeta.pl/ Zdrowie/1,105806,15879667,3_umiejetnosci__ktore_posiadly_osoby_w_ szczesliwych.html\#TRrelSST)

Walker V. (2010), The art of comforting: what to say and to do forpeople in distress, Penguin Books Ltd, London.

Winch G. (2013), Emotional first aid: practical strategies for treating failure, rejection, guilt, and other everyday psychological injuries, Penguin Group, New York.

Zdybel D. (2009), Linguistic perspective on emotional support - the study of comforting skills development in children [in:] K. Turowski (ed.), Wellness and success, Vol.3, NeuroCentrum, Lublin. 